2013

\title{
Power Relations in the Samaria Ostraca
}

Roger S. Nam

George Fox University, rnam@georgefox.edu

Follow this and additional works at: https://digitalcommons.georgefox.edu/gfes

Part of the Religion Commons

\section{Recommended Citation}

Nam, Roger S., "Power Relations in the Samaria Ostraca" (2013). Faculty Publications - Portland Seminary. 113.

https://digitalcommons.georgefox.edu/gfes/113

This Article is brought to you for free and open access by the Portland Seminary at Digital Commons @ George Fox University. It has been accepted for inclusion in Faculty Publications - Portland Seminary by an authorized administrator of Digital Commons @ George Fox University. For more

information, please contact arolfe@georgefox.edu. 


\title{
POWER RELATIONS IN THE SAMARIA OSTRACA
}

\author{
Roger S. Nam
}

Whereas recent studies have correctly identified a clan-based social structure presumed in the place names of the Samaria Ostraca, an analysis of the power relations within these structures has not been sufficiently developed. Approaching the evidence from a consumption perspective of the commodities for yn y's ('aged wine') and smn rhș ('washed oil') suggests that the economic significance of these items is tied to complex social interactions. Specifically, both archaeological and ethnographic studies associate such prestige commodities with elite feasting and ceremonial displays. By gifting these items, the central power engaged in a form of 'competitive feasting' to secure political capital for future use from clan leaders of the periphery of Samaria. Accordingly, the Samaria Ostraca hint at the use of redistributive mechanisms to secure power relations at elite gatherings.

Keywords: Samaria Ostraca, reciprocity, redistribution, feasting, consumption, olive oil, wine, Iron Age

\section{INTRODUCTION}

The Samaria Ostraca (hereafter SO) represent one of the most significant epigraphic finds of ancient Israel, though a century after their discovery, scholarship has yet to fully recognise the significance of this corpus in reconstructing Samaria's ancient economy. Much of the secondary literature focuses on the syntactical function of the single lamed preposition, which precede personal names. Several interpretations suggest that the SO recorded some form of taxation. Early in the study of the SO, Noth theorised that the $l$-men served as government officials recording the shipments to the royal house (Noth I927, 21I-244; Shea 1977, 26). Yadin (I959, I84-I87), Cross (I975, 8-го), Y. Aharoni (I979, 364-367), Kaufman (i982, 235238) and Renz (I995, 8I-84) all argue in some form that the $l$-men were not recipients, but rather the estate owners, and that the $\mathrm{SO}$ serves as receipts for centralised taxation. Both of these interpretations meet resistance in the form of two significant details: (I) some of the ostraca have no $l$-men and some have multiple $l$-men; and (2) the SO measure the quantity with the metrological term $n b l$. Though the precise quantity represented by a $n b l$ remains unknown, it certainly is too materially insignificant of a quantity for taxation (Niemann 2008, 252). In fact, several of the ostraca do not list any measurement, a curious phenomenon, if indeed the collection of oil and wine represented a major centralisation of these two resources.

To account for the divergence of $l$-men and the small quantities, Rainey (I967, 32-4I; I970, 45-5I; I979, 9I-94) argued that the SO marked a collection of goods, from royal estates, for distribution to royally-sponsored beneficiaries who lived within the city of Samaria. Specifically, Rainey identified such beneficiaries as members of a royal court. Schloen (2001, I63-I64) supports the general notion of $l$-men as recipients and not payers, and he mostly emphasises the correlation of the personal names and geographic names to the biblical description of the Manassite clans. Niemann (2008, 246-249) presupposes both Rainey's interpretation of $l$-men as recipients and Schloen's identification of the Manassite clans, but claims that the spatial distribution of the geographic names suggests a more deliberate political move in the transport of wine and oil to Samaria. He attributes the

Address correspondence to: Roger S. Nam, Department of Biblical Studies, George Fox University, I2753 SW 68th Avenue, Portland, Oregon, USA, rnam@georgefox.edu 
commodities as political gifts to the Manassite clan leaders to consolidate support for the Jehu monarchy.

The difficulties over the interpretation of the $l$-men transfer to a lack of resolve over the function of the SO. With such an impasse, adopting a new vantage point has the potential to galvanise dialogue regarding the political and economic nature of the SO. This article attempts to do so by focusing on the aspects of consumption rather than production or exchange. Anthropological studies of consumption focus on the political significance around any form of meal. Applied to the SO, this study examines the unique terms of $y n$ y s $^{\prime}$ ('aged wine') and šmn rhs ('washed oil') as ultra-elite commodities to explore the facets of consumption, which covers eating but also includes social settings and ramifications. The emphasis on these commodities in consumption draws attention to the complex social interactions in Samaria among the elite, whether mediated by a royal court (Rainey ig62, 62-63; ig67, 32-4I; I979, 9I-94) or regional tribal leaders (Niemann 2008, 249-266). Specifically, this study suggests that the recipients consumed the $\mathrm{SO}$ commodities, in a royal display of 'competitive feasting', as defined by anthropology (Brumfiel I994; Stanish 2003). Accordingly, this article argues that the aged wine and washed oil functioned as royal reciprocal gifts to consolidate the power of the Israelite King Joash or Jeroboam II. ${ }^{1}$

\section{THE GONSUMABLES: AGED WINE AND WASHED OIL}

Mary Douglas brought attention to the importance of meal consumption as indicative of the greater social system. In her seminal article, 'Deciphering a meal', she writes:

If food is treated as a code, the message it encodes will be found in the pattern of social relations being expressed. The message is about different degrees of hierarchy, inclusion, and exclusion, boundaries and transactions across the boundaries. (Douglas 1972, 6I)

Douglas specifically referred to the purity laws associated with common meals in Israel's household. The wider ramification of this perspective of consumption suggests that the royal meal is not mundane, but rather symbolises a complex palette of social realities in $8^{\text {th }}$-century BC Samaria.

A focus on the economic activity of consumption begins with the technical terms for the commodities, yn y̌̆n and $\check{s} m n$ r rhș, which underscore the ultra-elite nature of these items. In all references but two, the SO lists not merely 'wine', but 'aged wine' ( $y n$ yšn). Specifically, the SO type I ostraca refer to these commodities and they follow a set pattern, 'In the ninth/tenth year, from GN, to PN, a nbl of aged wine', though sometimes the GN and PN phrases are reversed. ${ }^{2}$

Suriano (2007, 30; citing parallel form with rhs; cf. Gibson I97ı, 8; Gogel I998, iı6, n. II3) identifies the $y \zeta^{n} n$ as an attributive adjective $(y \bar{a} s \bar{a} n)$, giving the attributive element an intransitive sense regarding its mode of production. The actual term yn $y s^{\grave{n}}$ does not occur in the Hebrew Bible (HB), but post-biblical and Akkadian texts use this term to refer to aged wine, often from the previous harvest (Paul 1975, 44; Frankel 1999, 200). Because of its association with aged wine, Suriano (2007, 30) suggests that it serves as the Northern semantic equivalent to the standard biblical Hebrew term šemārim ('wine'). Whereas the term šmārîm denotes inferior wine in later Jewish sources, the biblical usage of the term denotes a high-quality product. The šemārîm wine was clearly an elite commodity for festive use rather than a daily staple. Isaiah 25:6 uses the term šemārim in describing the essence of a fine banquet. Jeremiah 48:II-I2 condemns Moab for its arrogant reliance on śemārîm. The following verse confirms its congruence to the $y n$ y šn by identifying the container of a $n b l$ as in the SO. Zephaniah I:I2 also associates šemārim with excessive luxury in a prophetic curse. These occurrences of šemārim contrast with the more generic term for wine, yayin. 
The production of luxurious yn y šn was a costly endeavour. Dalman $(1935,373)$ suggests a rather lengthy process of letting this aged wine sit in dregs for longer periods. By taking up precious fermenting capacities, this aged wine was more costly to produce. Suriano (2007, $3^{0-3}$ I) identifies the Iron Age installations of Gibeon as possible evidence of multiple fermentations and aging, as well as several presses along the northern area of Manasseh with multiple vats (Ahlström I978, 4I-42; Suriano 2007, 3I). The interpretation of multiple vats with an elongated aging process is admittedly speculative, but such a cumbersome process is congruent with the exotic nature of aged wine in the ancient Near East.

Similar to the listing of wine, the SO highlights the oil as 'washed oil' (šmn rhss). The ostraca consistently use the standard pattern, 'In the ninth/tenth year, from GN, to PN, a $n b l$ of washed oil', though again, the phrase with the GN and PN can be reversed. ${ }^{3}$ In fact, the II3 inscriptions do not make a single identification to mere 'oil' without the modifier rhs. Similar to yn $y \check{s} n$, the vocalisation of the nomen rectum has inspired considerable discussion. Several scholars vocalise the $r h s ̣$ as an abstract noun (rohaș), thus indicating the function of the oil for bathing (Amar 2009, I9), purification (Gibson I971, 8; Lemaire 1977, 45-47; Demsky 2007, 333-336) or even as a cleaning agent (Lipiński i977, 85-86). Translation of the term as an active participle $(r \bar{a} h \bar{a} s \underline{s})$ can produce the same semantic meaning of function (Diringer 1934, 37-38; Joüon and Muraoka 2006, I36).

Several scholars see the nomen rectum as indicative of the production process and not the intended function. In vocalising $r h ̣ s$ as a Qal passive participle (rāhusṣ), Sasson (I98I, 4) suggests that the oil must undergo a refining process in accord with usage of rhs in certain biblical texts. ${ }^{4}$ Stager $\left(1983,24 \mathrm{I}^{-}-245\right)$ agrees with the grammatical tagging, but disputes the interpretation that $r h s$ necessarily refers to a chemically refining process. In accord with its northern provenance, Stager (24I) suggests that šmn rhṣ finds better linguistic analogy with 'crushed oil' ( comparisons to ethnographic observations around Samaria, suggesting that the Israelites crushed the olives, washed them in hot or cold water, and then skimmed off the oil. Then, the remaining pulp was heated in a rectangular pit for a second skimming. This first stage produced the finest quality of oil compared to the latter stage of pressing the pulp. This process was still practised in Palestinian communities in the $20^{\text {th }}$ century. Material culture supports this method of washing to produce oil around Samaria, particularly in the use of vats without the presses necessary for šmn ktt. Syntactical observations by both Lemaire (1977, 46-47) and Gogel (1998, I16) suggest that the participle explains the quality of the oil according to the production processes.

The presence of installation bins may indicate that the first skimming resulted in such washed oil. Clues from material culture reveal that the production of olive oil as šmn rhs was not efficient compared to other production methods. In an experimental study at Khallet e-Gazaz, along the north-western slope of the Samaria hills, Eitam (1993, 76-90) identifies 78 rock-cut installations, mostly dated to either the Chalcolithic period or the Iron Age I after a lengthy gap in settlement. Eitam's experiments suggest that the installations had much greater capacity for producing šmn ktt rather than šmn rḥs by as much as a $45 \%$ greater efficiency (1993, 77). This has significant implications for the specific listing of the smn rhs in the SO. They certainly knew of more efficient techniques, and many olive oil installations with efficient beams probably produced such šmn ktt in quantities far beyond internal consumption. Surplus oil went to pay for other goods. It appears that the SO document the deliberate inefficient production and distribution of high-quality šmn rhṣ for gifting in socially-embedded exchange.

The SO usage of the term nbl confirms the rare and precious nature of washed oil and aged wine. The term appears ten times in the HB, always in the context of a small, transportable load. ${ }^{6}$ This contrasts sharply with other Hebrew ostraca that document redistribution with significant quantities such as Tel Qasile I, which requests 'thousand and one 
hundred measures of oil to the king' (Dobbs-Allsopp et al. 2005, 402). The royal lmlk seals appear on large pottery vessels more appropriate for redistribution than simple household usage (Kletter 2009, 357). But rather than quantity, the usage of $n b l$ emphasises goods of high quality and social value. The $\mathrm{HB}$ uses the term $n b l$ for carrying loads specific for sociallyembedded exchanges, when the giver of the $n b l$ of wine seeks to establish a reciprocal relationship. In I Samuel I:24, Hannah brings a $n b l$ of wine to the temple, along with three bulls and flour in hopes that the Shiloh temple will take in her anointed son, Samuel. ${ }^{7}$ In I Samuel ı:3, Samuel instructs Saul to meet a group of men at Tabor and receive the gift of a $n b l$ of wine. Similarly, in an Ugaritic enthronement ritual, the oil comes forth from a $n b l$ (Fisher and Knutson I969, I57-167). In all of these examples, the quantity of $n b l$ never suggests large-scale centralisation or long-distance trade. ${ }^{8}$ Rather, the $n b l$ unit appears to occur with a socially-embedded form of gifting on a smaller scale.

Although the SO are limited to eight total lexemes outside of personal and geographic names, these lexemes reveal that the archive does not record mere ordinary oil and wine, but the finest quality of $\check{s} m n$ rhș and $y n y s ̌ n$. The identification of the SO of these as elite commodities, in terms of both high quality and scarce quantity, allows for an understanding of privileged consumption, and subsequently a new perspective on the political economy of the SO.

\section{GONSUMING WINE AND OIL IN ANTHROPOLOGIGAL PERSPEGTIVE}

With the relative absence of epigraphic data in the Iron Age IIB southern Levant, one can turn to anthropological research on the consumption of wine and oil for fresh perspective on the SO. Anthropological studies in consumption focus on social meanings prescribed to objects (Carrier 1998). These anthropological studies began to appear in the $19^{\text {th }}$ century with the publication of Mallery's Manners and Meals (I888), and Smith's chapter on feasts in Lectures on the Religion of the Semites (1889). Although vastly different in orientation, both studies examined the ways in which cultures used food as symbolic objects with larger social ramifications. The studies of consumption, not necessarily limited to food, continued to develop alongside anthropology with important early works by Boas (I92I) and then structuralist approaches by Lévi-Strauss (1965) and symbolic approaches by Douglas (1966, I979). Many of these consumption studies act as a foil to other economic perspectives. Contrary to both formalist and Marxist theories, a focus on consumption emphasises the social meaning embedded within objects. Objects certainly can have a material function, as pure eating and drinking, but ultimately, these objects carry symbolic implications, which can regulate the social world. Anthropologists seek to uncover the complex social ramifications of these objects. As a result, recent consumption studies touch on all kinds of aspects of eating: belief systems, ritual value, contested taxonomies, social rank, insecurities and identities (Mintz and Dubois 2002). Peripherally, these studies can investigate particular consumption phenomena in relation to food and their wider effects, such as shortage, taboo, cannibalism and psychoactive substances. Neither formalism nor Marxism sufficiently account for these social implications associated with eating.

A consumption perspective provides a suitable alternative to more prevalent theories of exchange in the ancient Near East. Polanyi's categorisation of exchange as reciprocity, redistribution and market exchange, cannot sufficiently explain the economic process within the SO. ${ }^{9}$ The inefficient production methods of the fine wine and oil, and the lack of any prices listed, negate the interpretation of any large-scale market exchange. The geographic spacing suggests centralisation, but the quantities are too meagre to support this as an example of major redistribution. This leaves reciprocity, but the parameters of Polanyian reciprocity do not necessarily match up with the social setting of the SO. In other words, one cannot assume the symmetry between the parties: $l$-men, non-l-men and the presumed royal family. 
With an emphasis on consumption, Stanish (2003, 2I) adds the fourth exchange mechanism of competitive feasting in light of ancient Titicaca. He defines competitive feasting as a form of 'deferred reciprocity'. But unlike most cases of reciprocity in Polanyi's paradigm, Stanish (12) declares:

The motive in competitive feasting is not the receipt of a future equal return of wealth but rather future political gain. Perhaps more so than in any other exchange mechanism, the political and the economic merge in competitive feasting ... the successful host or giver may actually lose total wealth in the short term but gains power and prestige.

Stanish continues by stating that competitive feasting has such a unique set of conditions outside the scope of reciprocity, redistribution and market exchange, yet competitive feasting appears in different contexts.

One of the interesting parallels between the anthropological studies on feasting and the $\mathrm{SO}$ revolves around the actual commodities of the feast. In order to successfully create a social connection, the quality of the feast must carry a high intrinsic value. Such commodities can 'attract followers, allies and patrons and ... maintain hierarchies of control' (Brumfiel I994, 6). With limited central force, the mere accumulation of these commodities depletes resources and is not tolerable. But the judicious usage of such commodities to build coalition is a vital aspect of creating and maintaining political power. Regional (clan?) leaders find themselves under the patronage of stronger leaders, and this coalition can grow into a powerful central authority. The distribution of ultra-elite commodities fuels such political transformation. Brumfiel (I994, II) suggests that:

The valuables used in these exchanges are scarce and highly valued, usually owing to their foreign origin or the quantity of labor involved in their production. The valuables are endowed with symbolic meanings that validate the alliances under construction; furthermore, the valuables are distributed in ritual contexts that further validate the relations of alliance.

Helms (I993, г60-170) gave classic articulation to such use of prestige commodities to manufacture and solidify political hegemony. Although she emphasised the usage of longdistance exotic goods, other studies recognise the suitability of locally-produced prestige goods to produce similar results (Junker I994, 230). For Samaria's aged wine and fine oil, it was not the proximity but rather the labour-intensive nature of the product that gave it prestige.

Closer to Iron Age Samaria, anthropological studies from ancient Crete validate the notions of political meaning in wine and oil. In a survey of archaeological evidence for oil and wine production in Bronze Age Crete, Hamilakis (I996, I-32) concludes that the prolific research on the economic aspects of wine and oil is insufficient because of the methodological emphasis on the actual exchange. Rather, he suggests that anthropological questions on consumption can better interpret data. In doing so, Hamilakis determines that the circulation of oil and wine follows a complex pattern, yet with better social indicators related to power and consolidation. He emphasises ' $[\mathrm{t}]$ he potential of wine and oil as items participating in complex social interactions such as feasting and drinking ceremonies and intra-élite gift exchange' (25). Hamilakis connects these ceremonies with their social ramifications, namely legitimisation of power. The usage of elite commodities finds parallel in Homeric political economy. In analysis of feasting in the Iliad and Odyssey, Rundin (I996, I79-2I5) emphasises two aspects of gifting: (I) articulation of the political hierarchy with the coordinator at the head; and (2) alliance through exchange. Rundin argues for the feast as the single dominant method of such a political network. These anthropological studies suggest that the $\mathrm{SO}$ corpus may underlie a socially-embedded exchange of royal feasting. 


\section{GONSUMING WINE AND OIL IN ANGIENT NEAR EASTERN TEXTS}

The ancient Near East is replete with examples of using wine in a way consistent with the concept of competitive feasting. The building of Assurbanipal II's new capital at Nimrud included vineyards capable of Io,0oo skins of wine for the inauguration ceremony (Sheratt I995, I8). In fact, the iconography of the royal banquet gives special prominence to wine in royal festivals as a symbol of power and fecundity. Nebuchadnezzar boasts of the vast preparations of wine for the gods (Powell I996, I08). It serves as a prominent political gift in Mari, as well as the royal court at Tell al-Rimah (I07).

Of course, ancient Near Eastern texts associate prestige with wine long before the Iron Age, although it appears to accelerate during the Neo-Assyrian period (Stronach I996, I92). Contemporaneous with the SO, the Nimrud Wine List corpus of 60 tablets shows specific distributions with variable quantities according to rank. The wine is given for specific festive occasions. Overall, the quantities were likely quite small ( $q a$, perhaps a single litre), roughly analogous to the $n b l$ (Kinnier Wilson I972, I I4). The provenience of the Nimrud Wine List falls under two spots, both being royal wine cellars, one in the Northwest Palace, and one in a local fort, placements geographically advantageous to the official quarters or royal recipients. Stronach (1996, I8I-203) cites several Neo-Assyrian reliefs that testify to the royal nature of wine. In an Assurnasirpal II relief, the king shares a cup with a servant who is also holding a cup while simultaneously protecting the king's wine with a fly-whisk. A $9^{\text {th }}$-century banquet scene on ivory shows another group of wine drinkers around a protected monarch. A Khorsabad relief shows a group of servants drawing wine with a zoomorphic vessel before attending to the banquet. Another scene shows the banquet with the esteemed guests enjoying the wine from the same-style vessels. Assyrian royal tombs have drinking bowls, further underscoring the importance of wine in festive occasions. Contemporary with the SO, these Neo-Assyrian examples freely used wine for ceremony and feast surrounding political legitimisation.

Similarly, the usage of washed oil likely carries similar political value and meaning. Oil was common to all classes, though the šmn rhș of the $\mathrm{SO}$ was much more valuable than a mere staple, particularly when considering it listed in parallel to the yn yšn. In fact, the washed oil likely has its best analogue in Akkadian (and Hittite) as 'fine oil' (Sumerian logograms: $\mathrm{I}_{3} . \mathrm{DUG}_{3}$.GA), ${ }^{10}$ a frequent gift and part of a feast in the Amarna texts ( $E A$ ii $50, \mathrm{I}_{7}: 44$, 22 iii $\left.36,{ }^{3} 26: 65\right)^{3}$. Ashurbanipal divination text invites the deity, during a sacred meal, to 'turn to the pure divine food, the best of the oil'. ${ }^{11}$

Therefore, both ethnographic accounts and comparative ancient Near Eastern evidence suggest that the commodities of washed oil and aged wine have deeply symbolic meaning, indicative of the political nature of the $\mathrm{SO}$ corpus. For the $\mathrm{SO}$, the recipients of these goods are now in association with the Israelite crown against all those that do not receive this elite consumable. The boundaries are drawn and the result is a consolidation of a central power, primarily during the reign of Jeroboam II.

\section{SYNTHESIS: AGED WINE AND WASHED OIL IN EIGHTH-GENTURY SAMARIA}

The perspective of consumption of these high-quality goods suggests that competitive feasting to build power relationships and allegiances underlie the SO corpus. An Israelite king distributed the aged wine and washed oil in an effort to buttress political support. Niemann (2008, 249-266) argued that the geographical distribution of the known personal names of the SO further confirm this interpretation. All the personal names, except one, are located $5^{-12} \mathrm{~km}$ from Samaria, easily a day's walk. ${ }^{12}$ Significantly, the majority of the shipments come from the western region of the Shechem Syncline, a region of banditry and instability, compared to the well-fortified settlements of the north and east of the syncline (Zertal 2004, 
7I-72). Such a spatially tight enclosure of loyal clans could serve the political needs of the ruling king, thereby necessitating the distribution of honour via elite commodities for a feast. The Samarian government would distribute limited quantities of and to the regional leaders, or $l$-men, according to their strategic importance. ${ }^{13}$ The regional leaders would then insure that the clans in turn would provide physical safety and economic access to the coastal plain and valuable sea routes. ${ }^{14}$

Although one cannot draw direct conclusions, the archaeology of $8^{\text {th }}$-century Samaria indicates a level of centralisation associated with elite political feasting. The royal acropolis reveals high-quality construction in expansion and alterations of buildings, as well as repair of a casemate wall along the northern edge of the summit. Along the western summit, a newly-erected multi-room storage house contained the SO, presumably alongside the commodities. Although exceedingly difficult to date (Tappy 200I, 49I-495), the presence of decorated ivories gives a tangible example of an elite product. The ceramic assemblage of $8^{\text {th }}$-century Samaria is rich and highly developed, indicating a developed craftsmanship during this period. Most significant among the $8^{\text {th }}$-century assemblage is so-called 'Samaria Ware', fine burnished, red slip vessels, which Kenyon described as 'the finest decorated ware of the Israelite period in Samaria' (Crowfoot et al. I957, I55). There is no indication that competitive feasts used these particular vessels, though they do indicate the presence of an elite culture connected to such feasting.

This analysis of the $\mathrm{SO}$ in light of consumption, rather than production or exchange, has yielded fresh perspectives regarding the power relationships within the society that produced the corpus. The study of yn yšn and šmn rhș suggests high quality and low quantity, suitable for competitive feasting. More than just reciprocal gifting, anthropological studies present a useful mechanism of competitive feasting to help unpack the political alliances that underpin the SO political economy. The vantage point of consumption and historical context of $8^{\text {th }}$-century Samaria allows for an attempt to connect the SO to the political and social development of the Northern Kingdom during the Iron Age II.

\section{ACKNOWLEDGEMENTS}

I wish to thank the Faculty Development Committee of George Fox University for generously funding this project with a Summer Research Fellowship. An earlier version of this article was presented at the Hebrew Bible, History and Archaeology programme unit of the Society of Biblical Literature in 2009. I especially would like to thank Chip Stanish for his insight on 'competitive feasting' as an exchange mechanism, and Matt Suriano for improving on ideas in this article. Marvin Chaney generously provided helpful comments on the geographic spacing of the SO. Of course, all positions and any errors are my own responsibility.

NOTES

\footnotetext{
${ }^{1}$ Scholars date the SO to both Joash $(804-789)$ and his son, Jeroboam II (788-748), or only Jeroboam II. Because the SO were not discovered in the context of good stratigraphy, scholars have turned to palaeography for most dating considerations. For a bibliography, see Niemann (2008, 265-266).

2 The references to the 'aged wine' appear in SO I, 3, 5, 6, 7, 8, 9, Iо, II, I2, I3, I4 and I5. Interestingly, the references to just 'wine', and not 'aged wine', come from royal vineyards (SO 53,54$)$.

${ }^{3}$ The references to the 'washed oil' appear in SO I6a, I6b, I7a, I7b, I8, I9, 20, 21 and 55. They also appear with the reference to wine in SO 53, 54 .

${ }^{4}$ Isa I:I6, 25 and Job 9:30-3I; 'The Qal passive participle mostly denotes a completed action or a state' (Joüon 2006, 388).
}

${ }^{5}$ Stager, though see objections in Suriano (2007, $32-33)$.

I Sam I:24; I0:3; 25:I8; 2 Sam I6:I; Isa 30:I4; Jer I3:I2; 48:12; Job 38:37; Lam 4:2. Aharoni (I979, 95-97) equates the $n b l$ to the Greek askos, citing the capacity from the Iron Age II examples to range from 0.65 to I.4 litres.

7 Other examples of the $n b l$ as a carrying capacity for socially-embedded exchange include: I Sam 25:I8; 2 Sam i6: I.

${ }^{8}$ For redistribution, the unit of the kor is a much more suitable measure for long-distance exchange as in the redistribution of I kilogramme 5:25.

${ }_{9}$ Polanyi (1957, 243-270).

10 The following abbreviations are used:

EA: El-Amarna tablets. According to the edition of J.A. Knudtzon. Die el-Amarna-Tafeln. Leipzig, 
I9o8-I9I5. Reprint, Aalen, ig64. Continued in A.F. Rainey, El-Amarna Tablets, 359-379. 2d revised ed. Kevelaer, 1978.

HB: Hebrew Bible.

SO: Samaria Ostraca, editio princeps published in Reisner, G.A. Fisher, C.S., and Lyon, D.G., I924. Harvard Excavations at Samaria I908-I9IO (vol. I, Cambridge, MA).

${ }^{11}$ Reiner I989, 328; cf. Lambert (1974, 277), line 48: 'Turn your face to the holy divine meal of fat and oil.'

${ }^{12}$ Aharoni (I979, 368, n. I22) matches the place name Yashub (SO 48) with Yasuf ig km away, though Schloen (200I, I59, n. 30) disputes this identification.

${ }^{13}$ Thus, Rosen (I986, 39-45) suggests two categories of $l$-men depending on the quantity of product.

${ }^{14}$ Niemann (2008, 260). But such conclusions do not necessarily support the notion of early state formation during the ascendancy of the house of Jehu (249-266). This runs counter to the impressive anthropological evidence. In Mesoamerica, the use of feasting with ultra-elite consumables often appears in the transition from chiefdom to tiered state system (Stanish 2003). But for the ancient Near East, such dialectical state formation does not hold. In fact, Master (200I, II7-I3I) dismisses such anthropological notions of progressive state formation by appealing to research on modern Middle East state formation by Khoury and Kostiner (I990). Their study concludes that, in the Middle East, groups move from tribe and state, but also can run back to tribe again. Most significantly, Master (200I, I27) suggests: 'Once the jump to statehood has been made, even in the presence of large empires or of modern state structures, tribal ties are still active throughout society.' By using tribal ties as the framework for administration, large polities are possible far beyond initial state formation, such as those in the Late Bronze Age Ugarit (Schloen). Therefore, the usage of the SO to garner support for the Nimshide dynasty does not identify the $8^{\text {th }}$ century as the point of early state formation.

\section{BIBLIOGRAPHY}

Aharoni, M., I979. 'The askos: is it the biblical nëbel?', Tel Aviv 6, 95-97.

Aharoni, Y., I979. The Land of the Bible: A Historical Geography, transl. A. F. Rainey, (revised and enlarged edn.), Philadelphia, PA: Westminster Press.

Ahlström, G. W., I978. 'Wine presses and cup-marks of the Jenin-Megiddo survey', BASOR 23I, I9-49.

Amar, Z., 2009. 'Smn rahuș', PEQ i41, i8-26.

Boas, F., I921. Ethnology of the Kwakiutl, Washington: Government Printing Office.

Brumfiel, E., I994. 'Factional competition and political development in the New World', in E. Brumfiel, and J. Fox (eds.), Factional Competition and Political Development, Cambridge: Cambridge University Press, 3-I4.

Carrier, J. G., I998. 'Consumption', in A. Barnard, and J. Spencer (eds.), Encyclopedia of Social and Cultural Anthropology, New York: Routledge, I28-i29.

Cross, F. M., I975. 'Ammonite ostraca from Heshbon', Andrewes University Seminary Studies I3, I-20.

Crowfoot, J. W., Crowfoot, G. M. and Kenyon, K. M., I957. Samaria-Sebaste III: The Objects, London: Palestine Exploration Fund.

Dalman, G., I935. Arbeit und Sitte in Palästina, Vol. 4, Gütersloh: C. Bertelsmann.

Demsky, A., 2007. 'Smn rhș: bath oil from Samaria', in S. White-Crawford, A. Ben-Tor and W. G. Dever (eds.), Up to the Gates of Ekron: Essays on the Archaeology and History of the Eastern Mediterranean in Honor of Seymour Gitin, Jerusalem: Israel Exploration Society, 333-336.

Diringer, D., i934. Le iscrizioni antico-ebraiche palestinesi, Florence: Le Monnier.

Dobbs-Allsopp, F. W., Roberts, J. J. M., Seow, C. L. and Whitaker, R. E., 2004. Hebrew Inscriptions: Texts from the Biblical Period of the Monarchy with Concordance, New Haven and London: Yale University Press.

Douglas, M., i972. 'Deciphering a meal', Daedalus гог, 6I-8I.

Douglas, M. and Isherwood, B., I979. The World of Goods: Towards an Anthropology of Consumption, New York: Basic Books.

Eitam, D., I993. "Between the [olive] rows, oil will be produced, presses will be trod..." (Job 24, I I)', in M. C. Amourette, and J. P. Brun (eds.), Oil and Wine Production in the Mediterranean Area (Bulletin de Correspondance Hellenique Suppl. 26), Paris: Caisse D'epargne de Toulon, 65-9o.

Fisher, L. R., and Knutson, F. B., I969. 'An enthronement ritual at Ugarit', Journal of Near Eastern Studies 28, I57-I67.

Frankel, R., I999. Wine and Oil Production in Antiquity in Israel and Other Mediterranean Countries (JSOT/ASOR Monograph Series io), Sheffield: Sheffield Academic Press.

Gibson, J. C. L., I971. Textbook of Syrian Semitic Inscriptions I: Hebrew and Moabite Inscriptions, Oxford: Oxford University Press.

Gogel, S. L., I998. A Grammar of Epigraphic Hebrew (Resources for Biblical Study 23), Atlanta, GA: Scholars Press.

Hamilakis, Y., I996. 'Wine, oil and the dialectics of power in Bronze Age Crete: a review of the evidence', Oxford Journal of Archaeology $\mathrm{I} 5, \mathrm{I}-32$.

Helms, M. W., i993. Craft and the Kingly Ideal: Art, Trade, Power, Austin, TX: University of Austin Press.

Joüon, P. and Muraoka, T., 2006. A Grammar of Biblical Hebrew (revised edn.), Rome: Editrice Pontificia Università Gregoriana.

Junker, L. L., I994. 'Trade competition, conflict, and political transformations in sixth to sixteenth century Philippine chiefdoms', Asian Perspectives 33, 229-260.

Kaufman, I. T., I982. 'The Samaria ostraca: an early witness to Hebrew writing', Biblical Archaeologist 45, $229-239$. 
Khoury, P. S. and Kostiner, J., I99o. Tribe and State Formation in the Middle East, Berkeley, CA: University of California Press.

Kinnier Wilson, J. V., I972. The Nimrud Wine Lists: A Study of Men and Administration at the Assyrian Capital in the Eighth Century B.C., London: British School of Archaeology in Iraq.

Kletter, R., 2009. 'Comment: computational intelligence, lmlk storage jars and the bath unit in Iron Age Judah', Fournal of Archaeological Method and Theory i6, 357-365.

Lambert, W. G., I974. 'Dingir.ša.dib.ba incantations', Fournal of Near Eastern Studies 33, 267-322.

Lemaire, A., I977. Inscriptions hébraïques (Littératures anciennes du Proche-Orient 9), Paris: CERF.

Lévi-Strauss, C., ig65. 'Le triangle culinaire', L'Arc 26, i9-29.

Lipiński, E., I977. 'North-west Semitic inscriptions', Orientalia Lovaniensia Periodica 8, 8I-II7.

Mallery, G., I888. 'Manners and meals', American Anthropologist I, I93-207.

Master, D. M., 200I. 'State formation theory and the kingdom of ancient Israel', Fournal of Near Eastern Studies 6o, II7-I3I.

Mintz, S. W. and Du Bois, C. M., 2002. 'The anthropology of food and eating', Annual Review of Anthropology 3I, 99-II9.

Niemann, H. M., 2008. 'A new look at the Samaria ostraca: the king-clan relationship', Tel Aviv 35, $249-266$.

Noth, M., 1927. 'Das Krongut der Israelitischen Könige und seine Verwaltung', ZDPV 50, 219-244.

Paul, S., I975. 'Classifications of wine in Mesopotamian and rabbinic sources', IEf 25, 42-44.

Polanyi, K., I957. 'The economy as instituted process', in K. Polanyi, C.M. Arensberg and H.W. Pearson (eds.), Trade and Market in the Early Empires, Glencoe, IL: Free Press, $243^{-270 .}$

Powell, M., I996. 'Wine and the vine in Mesopotamia: the Cuneiform evidence', in P. McGovern, S. J. Fleming and S. H. Katz (eds.), The Origins and Ancient History of Wine, New York: Gordon and Breach, 96-I24.

Rainey, A., I962. 'Administration in Ugarit and the Samaria ostraca', IEf ı2, 62-63.

Rainey, A., I967. 'The Samaria ostraca in the light of fresh evidence', PEQ 99, 32-4I.

Rainey, A., I970. 'Semantic parallels to the Samaria ostraca', PEQ io2, 45-51.

Rainey, A., I979. 'The Sitz im Leben of the Samaria ostraca', Tel Aviv 6, 9I-94.

Reiner, E., et al. (eds.), I989. The Assyrian Dictionary of the Oriental Institute of the University of Chicago: Š Part I, Chicago, IL: University of Chicago Press.

Renz, J., I995. Die Althebräischen Inschriften: Teil I: Text und Kommentar. Handbuch der Althebräischen Epigraphik, Darmstadt: Wissenschaftliche Buchgesellschaft.

Rosen, B., I986. 'Wine and oil allocations in the Samaria ostraca', Tel Aviv I3, 39-45.

Rundin, J., I996. 'A politics of eating: Feasting in early Greek society', American fournal of Philology II7, I79-2I5.

Sasson, V., I981. 'Šmn Rḥ̣ in the Samaria Ostraca', Journal of Semitic Studies 26, I-5.

Schloen, J. D., 200I. The House of the Father as Fact and Symbol: Patrimonialism in Ugarit and the Ancient Near East (Studies in the Archaeology and History of the Levant 2), Winona Lake, IN: Eisenbrauns.

Shea, W., I977. 'The date and significance of the Samaria ostraca', IE7 27, I6-27.

Sherratt, A., I995. 'Alcohol and its alternatives: symbol and substance in pre-industrial cultures', in J. Goodman, P. E. Lovejoy and A. Sherratt (eds.), Consuming Habits: Drugs in History and Anthropology, New York: Routledge, II -46 .

Smith, W. R., I889. Lectures on the Religion of the Semites, New York: A. and C. Black.

Stager, L. E., I983. 'The finest olive oil in Samaria', Fournal of Semitic Studies 28, 24I-245.

Stanish, C., 2003. Ancient Titicaca: The Evolution of Complex Societies in Southern Peru and Northern Bolivia, Berkeley, CA: University of California Press.

Stronach, D., i996. 'The imagery of the wine bowl: wine in Assyria in the early first millennium B.C.', in P. McGovern, S. J. Fleming and S. H. Katz (eds.), The Origins and Ancient History of Wine, New York: Gordon and Breach, I8I-203.

Suriano, M., 2007. "A fresh reading for "aged wine" in the Samaria ostraca', PEQ I39, 27-33.

Tappy, R., 200I. The Archaeology of Israelite Samaria: Volume II: The Eighth Century BCE (Harvard Semitic Studies 50), Winona Lake, IN: Eisenbrauns.

Yadin, Y., I959. 'Recipients or owners: a note on the Samaria ostraca', IEf 9, I84-187.

Zertal, A., 2004. The Manasseh Hill Country Survey, Volume I: The Shechem Syncline (Culture and History of the Ancient Near East 2I), Leiden: Brill. 